\title{
When can surfactants enhance hydrocarbon biodegradation in oil biotreatments?
}

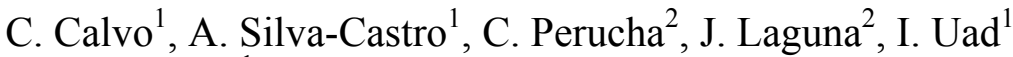 \\ \& J. G. López ${ }^{1}$ \\ ${ }^{I}$ Department of Microbiology, Institute of Water Research, \\ University of Granada, Spain \\ ${ }^{2} A G$ Ambiental, Madrid, Spain
}

\begin{abstract}
Petroleum hydrocarbon compounds bind to soil components and are difficult to remove and degrade. Surfactants and emulsifiers can emulsify hydrocarbons enhancing their water solubility, and increasing the displacement of oily substances from soil particles.

The effects of the Ivey surfactant on oil hydrocarbon biodegradation was studied using microcosm systems containing three different soil types amended with commercial NPK fertilizer. Microbial activity was evaluated following growth of heterotrophic and degrading microorganisms, dehydrogenase activity and production of $\mathrm{CO}_{2}$. Hydrocarbon degradation was established by determining the amount of TPH (total petroleum hydrocarbon) and alkanes, the indices $\mathrm{nC} 18 /$ phytane and pristane/ $\mathrm{nC} 17$ and the percentage of prystane and phytane.

Ivey surfactant augmented the amount of hydrocarbon removed in both clay and sandy soil. This indicates that surfactant could play an important role as a biostimulating agent at the beginning of the process and in combination with a nutrient addition. Also, CG/SM analyses have shown changes in hydrocarbon composition related to the rate of biodegradation
\end{abstract}

Keywords: surfactant, biodegradation, hydrocarbon.

\section{Introduction}

Bioremediation methods use microorganisms that occur naturally in the environment and degrade (mineralise) contaminants to less toxic or harmless 
products. Biological processes have been used successfully to remediate soils contaminated with petroleum hydrocarbons and their derivatives [9]. Several petroleum hydrocarbons can act as a source of carbon and energy for the growth of soil microorganisms.

Bioremeditaion has become an important method for the restoration of petroleum and other hydrocarbon pollutants from the environment [8]. It is considered an environmentally acceptable way of eliminating oils and fuel because the majority of hydrocarbons in crude oils and refined products are biodegradable, and hydrocarbons degrading microbes are ubiquitous [7].

Petroleum hydrocarbon compounds bind to soil components and are difficult to remove and degrade. Bioemulsifiers can emulsify hydrocarbons enhancing their water solubility and increasing the displacement of oily substances from soil particles [2]. For these reasons, inclusion of bioemulsifiers in a bioremediation treatment of a hydrocarbon polluted environment could be really advantageous. In situ flushing with surfactants and cosolvents recently has been emerging as a successful means of remediation of contaminated soils and groundwater.

In consequence, biosurfactant and other natural emulsifying agents are important tools for biotreatment of a hydrocarbon polluted environment $[4,10]$.

This paper presents the results from study the efficacy of Ivey surfactant, combined with NPK fertilizer, as biostimulating agent to oil hydrocarbon biodegradation under different experimental conditions.

\section{Materials and methods}

\subsection{Microcosms assays}

In these experiments, three types of soil have been studied; clay soil whose composition is $80 \%$ clay and $20 \%$ sand, sandy soil composed of $80 \%$ sand and $20 \%$ clay, both of these were contaminated in the laboratory with $20000 \mathrm{mg} / \mathrm{Kg}$ of diesel. The third one was a franc-clay soil composed of $36 \%$ clay, $33 \%$ sand and $10 \%$ slime; it was contaminated at source and provided by AG Ambiental.

Flask microcosms were performed in a $500 \mathrm{ml}$ Erlenmeyer flask, containing $250 \mathrm{~g}$ of uncontaminated soil (sandy and clay) $+20,000 \mathrm{mg} / \mathrm{Kg}$ of diesel and 50 $\mathrm{ml}$ of water (to keep the moisture). They were incubated a $28^{\circ} \mathrm{C}$ for 14 days. Assays of franc-clay soil contaminated at source were measured at $28^{\circ} \mathrm{C}$ for 14 days but without addition of diesel.

Soil microcosms were built in cylinder flask of $22 \mathrm{~cm}$ diameter and $10 \mathrm{~cm}$ deep with $4 \mathrm{Kg}$ of soil and they were incubated at room temperature for 21 days. Each experiment was tested weekly.

All the soil samples (except control samples) were amended with $0.3 \mathrm{~g}$ of NPK fertilizer $/ \mathrm{kg}$ of soil. This fertilizer is an inorganic complex fertilizer composed of $18 \%$ total nitrogen (nitrate, $1.2 \%$; ammonium, 3.1\% and urea $13.7 \%), 8 \%$ of $\mathrm{P}_{2} \mathrm{O}_{5}, 2 \%$ of $\mathrm{MgO}, 19 \%$ of $\mathrm{SO}_{3}$ and $0.5 \%$ of $\mathrm{Fe}$. It was provided by Agroblem S.L.

The Ivey-sol ${ }^{\mathbb{B}}$ (Ivey International Inc.) is a non-ionic surfactant; comprised of several proprietary formulations that works separating petroleum hydrocarbons 
and PAH's from contaminated soils, bedrock and the groundwater table. This surfactant was added to the flask microcosms and soil microcosms at a final concentration of $5.2 \mu \mathrm{l} / 100 \mathrm{~g}$ and $520 \mu \mathrm{l} / 100 \mathrm{~g}$, respectively.

\subsection{Enumeration of culturable bacteria in soil}

Three replicate samples from each microcosm treatment were withdrawn every week for enumeration of aerobic heterotrophic bacteria and oil degrading bacteria. $0.1 \mathrm{ml}$ of serially diluted soil samples were plated in 1/10 diluted Trypticase Soy Agar (TSA, Difco). Degrading bacteria were counted in $1 \%$ hydrocarbon trypticase soy agar. Triplicate plates were incubated at $28^{\circ} \mathrm{C}$ for 48 $\mathrm{h}$ before the colonies were counted.

\subsection{Biological activity}

Dehydrogenase activity was determined by the reduction of 2,3,5tryphenylterazolium chloride (TTC) to tryphenyl formazane (TPF). Ten $\mathrm{ml}$ of TTC solution (1\%) and $1 \mathrm{ml}$ of distilled water were added to $10 \mathrm{~g}$ of soil samples mixed with $0.1 \mathrm{~g}$ of $\mathrm{CaCO}_{3}$. After $24 \mathrm{~h}$ incubation at $25^{\circ} \mathrm{C}$, the reaction product, TTF was extracted with methanol and the absorbance measured at $485 \mathrm{~nm}$.

Soil samples for the respiration test were incubated in a closed vessel at $28^{\circ} \mathrm{C}$ [5]. The $\mathrm{CO}_{2}$ produced was detected by gas chromatography (Varian Star 3400 cx, with TCD Detector)

\subsection{Hydrocarbon analyses}

Total petroleum hydrocarbons were extracted from the soil samples with a mixture of hexane: acetone $1: 1(\mathrm{v} / \mathrm{v})$ and determined by gravimetric analysis according to Aguilera-Vázquez et al. [1].

Analysis of each hydrocarbon fraction were performed from the extracted fractions above mentioned using a Hewlett-Packard 6890 GC system equipped with a HP-5-MS-capillary column $(30 \mathrm{~m} \times 0.32 \mathrm{~mm}$ I.D.). Helium $(1.6 \mathrm{ml} / \mathrm{min})$ was utilised as carrier gas. The determinations were performed using the following temperature program: $40^{\circ} \mathrm{C}$ held 1 min isothermal, heating rate $4^{\circ} \mathrm{C} / \mathrm{min}$ up to $310^{\circ} \mathrm{C}$, final temperature held for $1.5 \mathrm{~min}$. Injector and detector temperatures were $250^{\circ} \mathrm{C}$ and $300^{\circ} \mathrm{C}$, respectively. $\mathrm{N}$-alkanes and $\mathrm{PAH}$ were detected using a mass detector 5872 (Hewlett-Packard) and a library utilized was Wiley 275.

\section{Results and discussion}

Microbial activity was evaluated following growth of heterotrophic and degrading microorganisms, dehydrogenase activity and production of $\mathrm{CO}_{2}$ (respiration test).

Figure 1 shows growth of heterotrophic and degrading microorganisms in Erlenmeyer flask microcosms treated with NPK fertilizer and NPK plus Ivey surfactant. In respect to the control experiments (without addition of any 
nutrient), treatment with NPK fertilizer or with NPK + Ivey surfactant enhanced microbial degrading populations in both sandy and clay flask microcosms contaminated in the laboratory (fig $1 \mathrm{~B}$ and D). However, no significant differences were found in flask microcosms with soil samples polluted at source (fig $1 \mathrm{E}$ and $\mathrm{F}$ ). It seems that in these microcosms, microbial populations were already adapted to oil hydrocarbon pollution.
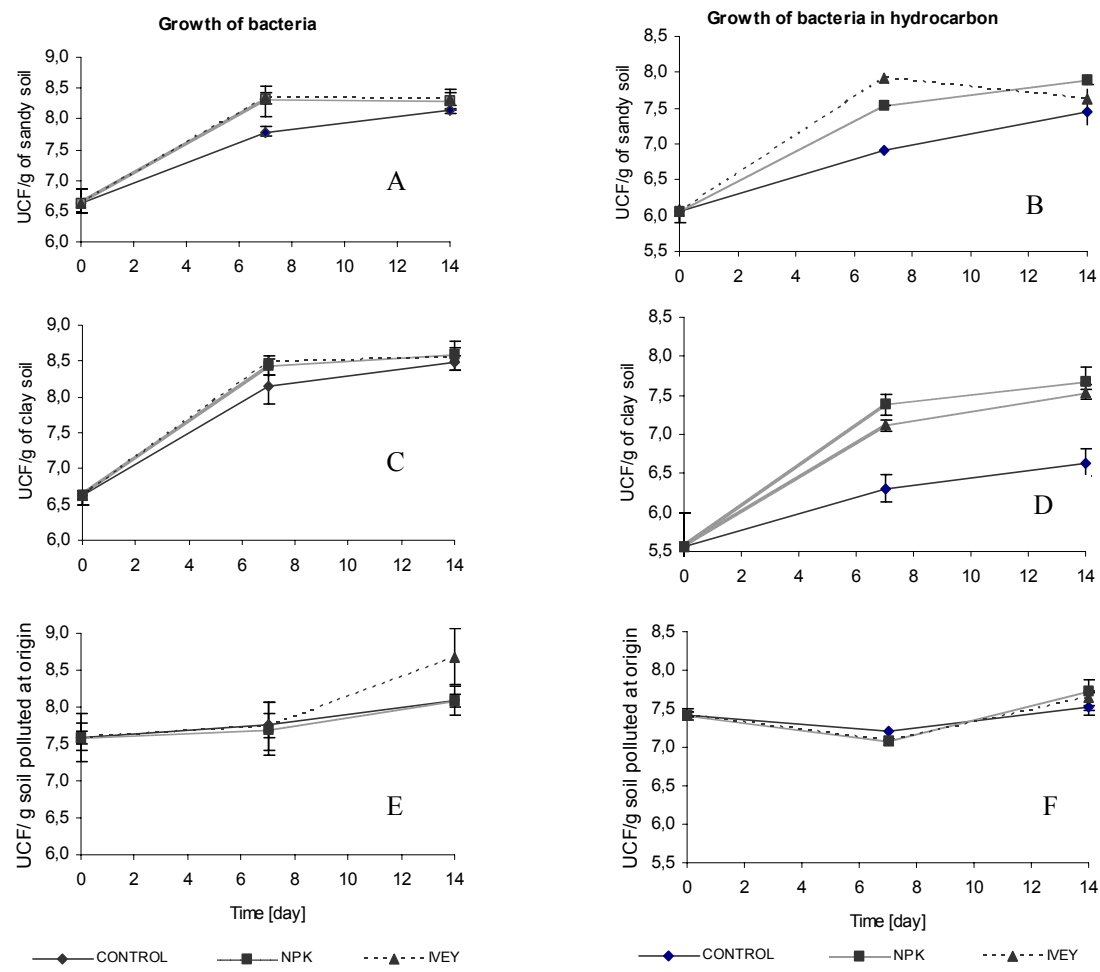

Figure 1: Number of total heterotrophic and degrading bacteria in flask microcosms.

Stimulation of microbial populations was correlated with high values of dehydrogenase activity and $\mathrm{CO}_{2}$ production measured at the end of experiments. These parameters showed a remarkable biological activity in microcosms polluted at source (Table 1). On the other hand, when Ivey surfactant was added to flask microcosms, the percentage of moisture was higher than in microcosms treated with NPK alone. Moisture is an important variable in soil habitat, it controls soil oxygen levels by competing with oxygen for soil pore spaces and microorganisms require water for proper growth [11].

Yields of hydrocarbon degradation can be evaluated by determining total amount hydrocarbons (TPH), aromatics and alkanes present in the soil samples but also by identifying the indices $\mathrm{nC} 18 /$ phytane and pristane/nC17 and the 
percentage of prystane and phytane. Changes in these indices were used as biomarkers of degradation processes hydrocarbons [6].

Table 1: Microbial activity estimated by moisture, dehydrogenase and production of $\mathrm{CO}_{2}$ in flask microcosm.

\begin{tabular}{|c|c|c|c|}
\hline \multicolumn{4}{|l|}{ Sandy Soil } \\
\hline \multirow[b]{2}{*}{ Treatment } & $\begin{array}{l}\text { \% Moisture } \\
t_{0}=14,1 \pm 1,1\end{array}$ & $\begin{array}{l}\text { Dehydrogenase } \\
t_{0}=58,3 \pm 10,3\end{array}$ & $\begin{array}{l}\mathbf{\%} \mathbf{C O}_{\mathbf{2}} \mathbf{2 4 h} \\
\mathrm{t}_{0}=0,09 \pm 0,002\end{array}$ \\
\hline & $\mathrm{t}_{14 \mathrm{~d}}$ & $\mathrm{t}_{14 \mathrm{~d}}$ & $\mathrm{t}_{14 \mathrm{~d}}$ \\
\hline Control & $14,0 \pm 0,5$ & $56,9 \pm 18,3$ & $0,12 \pm 0,02$ \\
\hline NPK & $14,0 \pm 0,8$ & $158,6 \pm 6,7$ & $0,22 \pm 0,03$ \\
\hline Ivey & $15,6 \pm 0,5$ & $121,1 \pm 0,0$ & $0,18 \pm 0,01$ \\
\hline \multicolumn{4}{|l|}{ Clay Soil } \\
\hline \multirow[b]{2}{*}{ Treatment } & $\begin{array}{l}\text { \% Moisture } \\
\mathrm{t}_{0}=24,7 \pm 0,6\end{array}$ & $\begin{array}{l}\text { Dehydrogenase } \\
t_{0}=62,4 \pm 9,9\end{array}$ & $\begin{array}{l}\mathbf{\%} \mathbf{~ C O} \mathbf{2 4 h} \\
t_{0}=0,11 \pm 0,009\end{array}$ \\
\hline & $\mathrm{t}_{14 \mathrm{~d}}$ & $\mathrm{t}_{14 \mathrm{~d}}$ & $\mathrm{t}_{14 \mathrm{~d}}$ \\
\hline Control & $23,5 \pm 0,8$ & $64,7 \pm 6,4$ & $0,034 \pm 0,01$ \\
\hline NPK & $22,8 \pm 0,4$ & $93,6 \pm 5,8$ & $0,090 \pm 0,01$ \\
\hline Ivey & $23,8 \pm 0,7$ & $74,0 \pm 1,3$ & $0,093 \pm 0,01$ \\
\hline \multicolumn{4}{|c|}{ Soil polluted at origin } \\
\hline \multirow[b]{2}{*}{ Treatment } & $\begin{array}{l}\text { \% Moisture } \\
\mathrm{t}_{0}=34,5 \pm 0,8\end{array}$ & $\begin{array}{l}\text { Dehydrogenase } t_{0} \\
=304,6 \pm 50,4\end{array}$ & $\begin{array}{l}\text { \% CO } \mathbf{2} \mathbf{2 4 h} \\
\mathrm{t}_{0}=0,38 \pm 0,03\end{array}$ \\
\hline & $\mathrm{t}_{14 \mathrm{~d}}$ & $\mathrm{t}_{14 \mathrm{~d}}$ & $\mathrm{t}_{14 \mathrm{~d}}$ \\
\hline Control & $34,2 \pm 1,5$ & $69,42 \pm 8,2$ & $0,10 \pm 0,01$ \\
\hline NPK & $31,5 \pm 2,4$ & $301,1 \pm 64,82$ & $0,16 \pm 0,02$ \\
\hline Ivey & $33,5 \pm 1,8$ & $371,5 \pm 52,4$ & $0,17 \pm 0,05$ \\
\hline
\end{tabular}

Gravimetrically TPH determination (fig 2) has shown that \% of TPH remaining in treated microcosms was always lower than in those non- treated. Also, Ivey surfactant augmented the amount of hydrocarbon removed in both clay and sandy soil. This seems indicate that addition of surfactant and inorganic fertilizer (NPK) could play an important role as a biostimulating agent at the beginning of the bioremediation process. CG/SM analyses have shown changes in hydrocarbon composition related to the rate of biodegradation.

Table 2 summarizes the results of flask microcosm assays. The data obtained indicated that microcosms treated with Ivey had the highest level of biodegradation. Thus, in sandy and clay flask microcosms $\mathrm{C}_{18} / \mathrm{Phy}$ rate and $\%$ Phy were reliable correlation indices. However, in flask microcosms containing soil samples contaminated at origin, $\mathrm{C}_{18}$ and $\mathrm{C}_{17}$ fractions were not detected and consequently the best correlation indices were \% Phytane and \% Pristane. Obviously, under these experimental conditions it could be suggested that the oil biodegradation had already begun. 


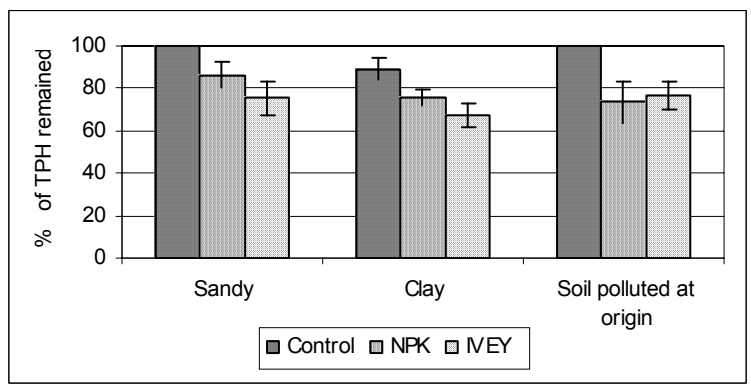

Figure 2: $\quad$ Rate of TPH degradation in flask microcosm.

Table 2: $\quad$ Correlation indices of biodegradation in flask microcosms.

\begin{tabular}{|c|c|c|c|c|}
\hline \multicolumn{5}{|l|}{ Sandy Soil } \\
\hline \multirow[b]{2}{*}{ Treatment } & $\begin{array}{l}\text { Pr/c17 } \\
\mathrm{T}_{0}=0,53\end{array}$ & $\begin{array}{l}\text { C18/Phy } \\
\mathrm{t}_{0}=1,71\end{array}$ & $\begin{array}{l}\text { \% Pr } \\
\mathrm{t}_{0}=7,20\end{array}$ & $\begin{array}{l}\text { \% Phy } \\
\mathrm{t}_{0}=5,93\end{array}$ \\
\hline & $\mathrm{t}_{14 \mathrm{~d}}$ & $\mathrm{t}_{14 \mathrm{~d}}$ & $\mathrm{t}_{14 \mathrm{~d}}$ & $\mathrm{t}_{14 \mathrm{~d}}$ \\
\hline Control & 0,80 & 1,66 & 7.97 & 6,21 \\
\hline NPK & 0,71 & 1,60 & 8,02 & 6,47 \\
\hline Ivey & 0,68 & 1,43 & 7,98 & 7,16 \\
\hline \multicolumn{5}{|l|}{ Clay Soil } \\
\hline \multirow[b]{2}{*}{ Treatment } & $\begin{array}{l}\text { Pr/c17 } \\
\mathrm{T}_{0}=0,48\end{array}$ & $\begin{array}{l}\text { C18/Phy } \\
t_{0}=1,42\end{array}$ & $\begin{array}{l}\text { \% Pr } \\
\mathrm{t}_{0}=5,87\end{array}$ & $\begin{array}{l}\text { \% Phy } \\
\mathrm{t}_{0}=7,40 \\
\end{array}$ \\
\hline & $\mathrm{t}_{14 \mathrm{~d}}$ & $\mathrm{t}_{14 \mathrm{~d}}$ & $\mathrm{t}_{14 \mathrm{~d}}$ & $\mathrm{t}_{14 \mathrm{~d}}$ \\
\hline Control & 0,43 & 1,61 & 5,53 & 7,35 \\
\hline NPK & 0,57 & 1,29 & 6,38 & 8,43 \\
\hline Ivey & 0,53 & 1,33 & 6,57 & 8,86 \\
\hline \multicolumn{5}{|c|}{ Soil polluted at origin } \\
\hline \multirow[b]{2}{*}{ Treatment } & Pr/c17 & C18/Phy & $\begin{array}{l}\text { \% Pr } \\
\mathrm{t}_{0}=15,57\end{array}$ & $\begin{array}{l}\text { \% Phy } \\
\mathrm{t}_{0}=16,73\end{array}$ \\
\hline & $\mathrm{t}_{14 \mathrm{~d}}$ & $\mathrm{t}_{14 \mathrm{~d}}$ & $\mathrm{t}_{14 \mathrm{~d}}$ & $\mathrm{t}_{14 \mathrm{~d}}$ \\
\hline Control & ND & ND & 25,50 & 28,43 \\
\hline NPK & ND & ND & 27,22 & 14,98 \\
\hline Ivey & ND & ND & 38,43 & 40,85 \\
\hline
\end{tabular}

In soil microcosms (figure 3), addition of nutrients (NPK) and surfactant stimulated both heterotrophic and degrading microbial populations at a similar rate to what was previously mentioned in relation with flasks microcosms. In the same way, results of biological activity showed higher values of dehydrogenase activity and $\mathrm{CO}_{2}$ production (Table 3 ). However, this effect was not observed in dehydrogenase activity of soil contaminated at origin. Benton et al described that a negative relationship between microbial population and microbial activity 
could indicate that specialized microorganisms were adjusting to the changing substrate conditions [3].
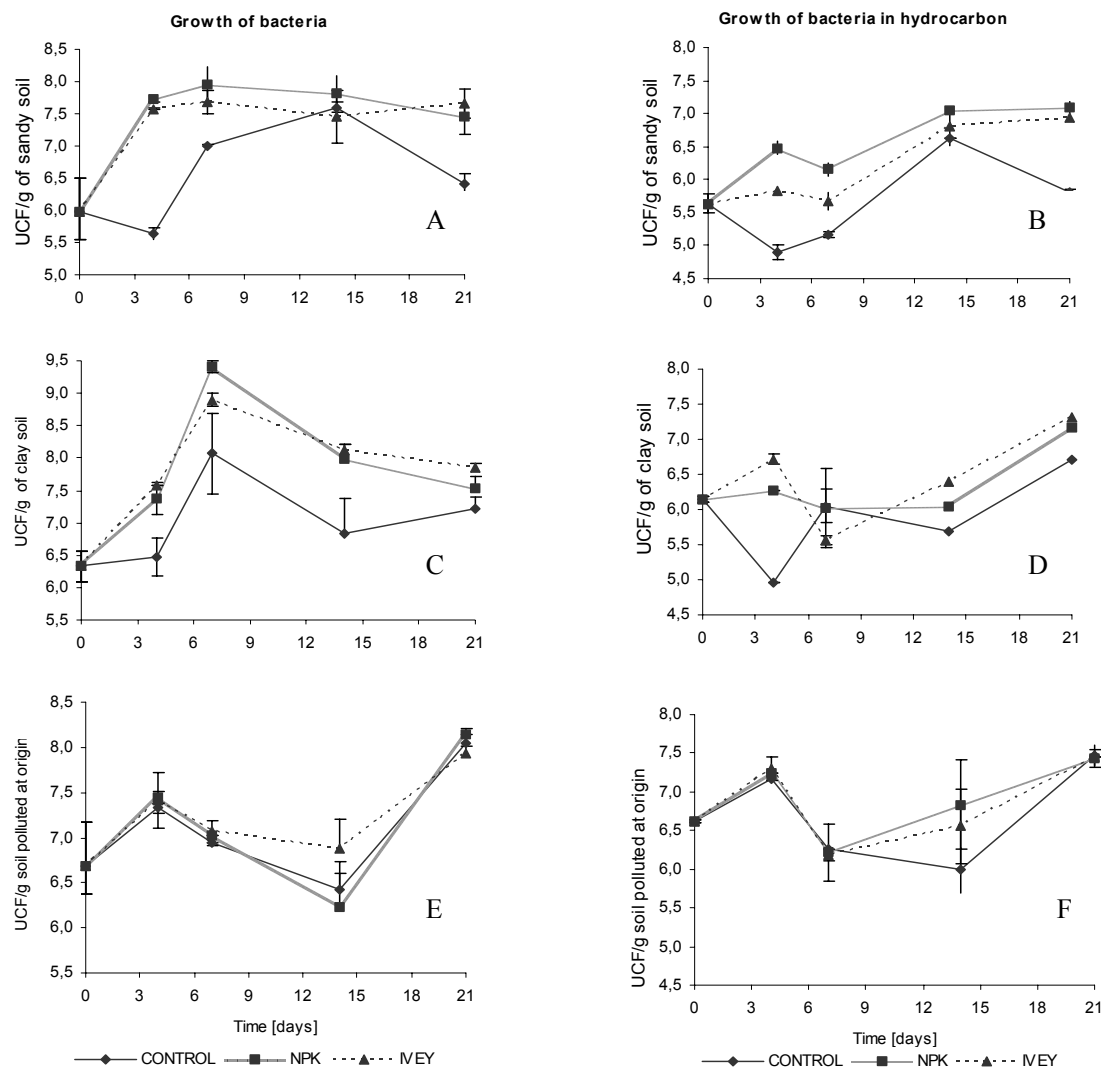

Figure 3: Number of total heterotrophic and degrading bacteria in soil microcosms.

TPH analyses demonstrated that TPH concentrations in sandy, clay and franc clay soils were not significantly affected by the addition of surfactant or inorganic fertilizer when compared with unamended soils (figure 4). But, as shown in table 4 the higher values of prystane and phytane percentages indicated a potential higher rate of biodegradation in Ivey clay microcosms. Furthermore, the $\mathrm{C}_{18}$ /phytane correlation indices of NPK clay microcosm point to earlier microbial activity.

Hydrocarbon degradation in terrestrial ecosystems may be limited by the available water for microbial growth and metabolism. A decrease in moisture content results in a decrease of microbial activity, and rewetting cause a large and rapid increase in activity. Microcosms of soil polluted at origin shown lower efficiency in TPH reduction, this could be related with the lost of microcosm moisture (near $15 \%$ percentage) in respect with the initial value [11]. 
Table 3: Microbial activity estimated by moisture, dehydrogenase and production of $\mathrm{CO}_{2}$ in soil microcosm.

\begin{tabular}{|c|c|c|c|}
\hline \multicolumn{4}{|l|}{ Sandy Soil } \\
\hline \multirow[b]{2}{*}{ Treatment } & $\begin{array}{l}\text { \% Moisture } \\
\mathrm{t}_{0}=18,1 \pm 1,6\end{array}$ & $\begin{array}{l}\text { Dehydrogenase } \\
t_{0}=98,8 \pm 11,1\end{array}$ & $\begin{array}{l}\mathbf{\%} \mathbf{C O}_{\mathbf{2}} \mathbf{2 4 h} \\
\mathrm{t}_{0}=0,034 \pm 0,001\end{array}$ \\
\hline & $\mathrm{t}_{21 \mathrm{~d}}$ & $\mathrm{t}_{21 \mathrm{~d}}$ & $\mathrm{t}_{21 \mathrm{~d}}$ \\
\hline Control & $16,4 \pm 1,8$ & $5,6 \pm 1,2$ & $0,032 \pm 0,01$ \\
\hline NPK & $15,9 \pm 0,01$ & $81,9 \pm 20,0$ & $0,156 \pm 0,01$ \\
\hline Ivey & $14,4 \pm 0,01$ & $66,5 \pm 6,2$ & $0,162 \pm 0,02$ \\
\hline \multicolumn{4}{|l|}{ Clay Soil } \\
\hline \multirow[b]{2}{*}{ Treatment } & $\begin{array}{l}\text { \% Moisture } \\
t_{0}=22,9 \pm 0,1\end{array}$ & $\begin{array}{l}\text { Dehydrogenase } \\
t_{0}=33,3 \pm 8,6\end{array}$ & $\begin{array}{l}\mathbf{\%} \mathbf{C O}_{\mathbf{2}} \mathbf{2 4 h} \\
\mathrm{t}_{0}=0,052 \pm 0,005\end{array}$ \\
\hline & $\mathrm{t}_{21 \mathrm{~d}}$ & $\mathrm{t}_{21 \mathrm{~d}}$ & $t_{21 d}$ \\
\hline Control & $21,0 \pm 0,6$ & $12,3 \pm 2,1$ & $0,050 \pm 0,03$ \\
\hline NPK & $19,4 \pm 0,6$ & $43,6 \pm 0,8$ & $0,171 \pm 0,02$ \\
\hline Ivey & $20,1 \pm 0,1$ & $18,6 \pm 1,7$ & $0,132 \pm 0,01$ \\
\hline \multicolumn{4}{|c|}{ soil polluted at origin } \\
\hline \multirow[b]{2}{*}{ Treatment } & $\begin{array}{l}\text { \% Moisture } \\
t_{0}=31,2 \pm 1,0\end{array}$ & $\begin{array}{l}\text { Dehydrogenase } \\
t_{0}=15,5 \pm 1,4\end{array}$ & $\begin{array}{l}\text { \% CO } \mathbf{2} \mathbf{2 4 h} \\
\mathrm{t}_{0}=0,064 \pm 0,003\end{array}$ \\
\hline & $\mathrm{t}_{21 \mathrm{~d}}$ & $\mathrm{t}_{21 \mathrm{~d}}$ & $\mathrm{t}_{21 \mathrm{~d}}$ \\
\hline Control & $15,6 \pm 0,9$ & $49,0 \pm 4,6$ & $0,127 \pm 0,009$ \\
\hline NPK & $14,4 \pm 0,5$ & $46,1 \pm 20,8$ & $0,170 \pm 0,082$ \\
\hline Ivey & $13,2 \pm 0,2$ & $34,4 \pm 4,2$ & $0,177 \pm 0,045$ \\
\hline
\end{tabular}

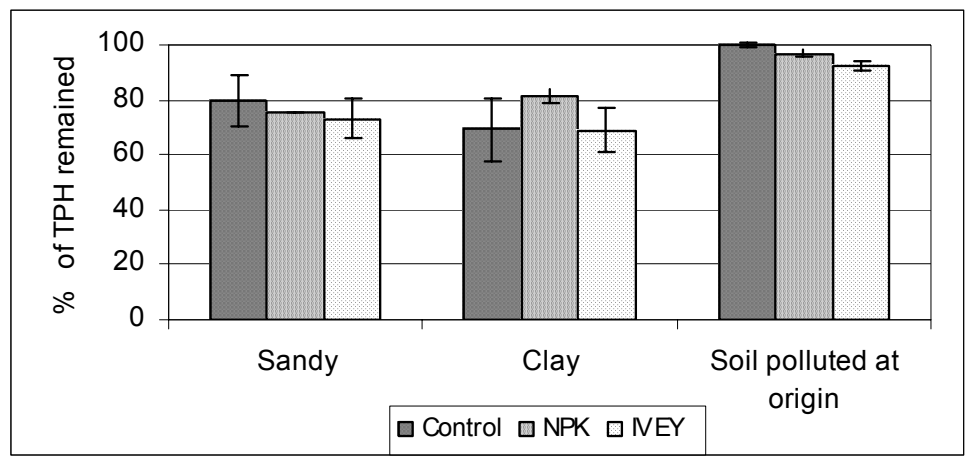

Figure 4: $\quad$ Percentage of degradation of total petroleum in soil microcosm.

Finally, GC/MS analyses showed the lack $\mathrm{C}_{17}$ and $\mathrm{C}_{18}$ in the soil polluted at origin, indicating that probably biodegradation was initiated some time ago and it agrees with biological activity mentioned above. 
Table 4: $\quad$ Biomarker compounds in soil microcosms.

\begin{tabular}{|c|c|c|c|c|}
\hline \multicolumn{5}{|l|}{ Sandy Soil } \\
\hline \multirow[b]{2}{*}{ Treatment } & $\begin{array}{l}\text { Pr/c17 } \\
\mathrm{T}_{0}=0,45\end{array}$ & $\begin{array}{l}\text { C18/Phy } \\
\mathrm{t}_{0}=3,26\end{array}$ & $\begin{array}{l}\% \mathbf{P r} \\
\mathrm{t}_{0}=3,69\end{array}$ & $\begin{array}{l}\text { \% Phy } \\
\mathrm{T}_{0}=3,50\end{array}$ \\
\hline & $\mathrm{t} 21 \mathrm{~d}$ & $\mathrm{t}_{21 \mathrm{~d}}$ & $\mathrm{t}_{21 \mathrm{~d}}$ & $\mathrm{t}_{21 \mathrm{~d}}$ \\
\hline Control & 0,47 & 3,20 & 4,91 & 3,41 \\
\hline NPK & 0,50 & 2,75 & 4,52 & 3,82 \\
\hline Ivey & 0,41 & 2,02 & 3,91 & 8,74 \\
\hline \multicolumn{5}{|l|}{ Clay Soil } \\
\hline \multirow[b]{2}{*}{ Treatment } & $\begin{array}{l}\text { Pr/c17 } \\
\mathrm{T}_{0}=0,43\end{array}$ & $\begin{array}{l}\text { C18/ Phy } \\
t_{0}=3,07\end{array}$ & $\begin{array}{l}\text { \% Pr } \\
\mathrm{t}_{0}=3,78\end{array}$ & $\begin{array}{l}\text { \% Phy } \\
\mathrm{T}_{0}=2,92\end{array}$ \\
\hline & $\mathrm{t}_{21 \mathrm{~d}}$ & $\mathrm{t}_{21 \mathrm{~d}}$ & $\mathrm{t}_{21 \mathrm{~d}}$ & $\mathrm{t}_{21 \mathrm{~d}}$ \\
\hline Control & 0,45 & 3,62 & 3,61 & 2,08 \\
\hline NPK & 0,43 & 2,85 & 2,35 & 1,71 \\
\hline Ivey & 0,49 & 3,26 & 5,03 & 2,93 \\
\hline \multicolumn{5}{|c|}{ Soil polluted at origin } \\
\hline \multirow[b]{2}{*}{ Treatment } & Pr/c17 & C18/ Phy & $\begin{array}{l}\text { \% Pr } \\
\mathrm{t}_{0}=5,47\end{array}$ & $\begin{array}{l}\text { \% Phy } \\
\mathrm{T}_{0}=6,64\end{array}$ \\
\hline & $\mathrm{t} 21 \mathrm{~d}$ & $\mathrm{t}_{21 \mathrm{~d}}$ & $\mathrm{t}_{21 \mathrm{~d}}$ & $\mathrm{t} 21 \mathrm{~d}$ \\
\hline Control & ND & ND & 9,95 & 8,81 \\
\hline NPK & ND & ND & 14,10 & 9,89 \\
\hline Ivey & ND & ND & 12,77 & 9,03 \\
\hline
\end{tabular}

\section{Acknowledgements}

This research has been supported by several projects of Ministerio de Educacion y Ciencia (CICYT: REN 200-0384-P4-02) and Ministerio de Medio Ambiente (Ref:579/2006/3-1.2 and A487/2007/20-01.1). We thank AG Ambiental Inc. for its collaboration

\section{References}

[1] Aguilera-Vázquez, L., Soto-Cruz, N. O., Saucedo-Castañeda, G. and Gutiérrez-Rojas, M. A. model system for composting hydrocarbon contaminated soil by using water activity and porosity as response variables. Chemical Engineering Journal 81, pp. 197-202, 2001.

[2] Banat, R.S. Makkar \& Cameotra S.S., Potential commercial applications of microbial; surfactants, Appl. Microbiol. Biotechnol., 53, pp. 495-508, 2000.

[3] Benton, F.M., Camargo, F. Okeke, B.C., Frankenberger, W.T. Comparative bioremediation of soils contaminated with diesel oil by natural attenuation, 
biostimulation and bioaugmentation. Bioresource technology 96, pp. 10491055, 2005.

[4] Barkay T., Nayon-Venezia S., Ron E.Z. \& Rosenberg E., Enhancement of solubilization and biodegradation of polyaromatic hydrocarbons by the bioemulsifier alasan, Appl. Environ. Microbiol. 65, pp. 2697-2702, 1999.

[5] Casidy, L.E., D.A. Klein and T. Santero. Soil dehydrogenase activity. Soil Sci. Soc. Am. J. 47, pp. 599-603, 1964.

[6] Dailing, P.S., Fakness, L.G., Hansen, A.B., Stout, S.A.. Improved and standardiesed methodology for oil spill fingerprinting. Environ Forensics 3, pp. 263-278,2001.

[7] Kanaly R. \& Harayama S. Biodegradation of high-molecular weight polycyclic aromatic hydrocarbons by bacteria. Journal of Bacteriology, 182, pp. 2059-2067, 2000.

[8] Leahy, J.G. \& Colwell, R. Microbial degradation of hydrocarbons in the environment. Microbiol Rev, 54, pp. 305-315, 1990.

[9] Mulligan C.N., Yong R.N. \& Gibbs B.F. surfactant-enhanced remediation of contaminated soil: Engineering Geology, 60, pp. 371-380, 2001.

[10] Ron E.Z. \& Rosenberg E., Biosurfactants and oil bioremediation, Curr. Opin. Biotechnol., 13, pp. 249-252, 2002.

[11] Scheutz, C., Mosbaek, H., and Kjeldsen P. Attenuation of methane and volatile organic compounds in landfill soil covers. J. Environ. Qual. 33, 6171, 2004. 